\title{
Comparative Advertising Wars: An Historical Analysis of Their Causes and Consequences
}

\section{Fred Beard'}

\begin{abstract}
This historical study contributes to the extensive literature on comparative advertising by examining the causes and consequences of comparative advertising wars; that is, when one advertiser responds to a direct or implied attack by another advertiser. Primary and secondary sources consist of articles published in historic and contemporary marketing and advertising trade journals, such as Printers' Ink, Advertising \& Selling, and Advertising Age. The findings reveal that well-publicized advertising wars occurred frequently between major U.S. advertisers throughout the twentieth century and into the twenty-first, and that they most often occurred in product and service markets characterized by intense competition. Many, if not most, advertisers' principal motive for responding to a comparative advertising attack has been emotional rather than rational. The findings also reveal that advertising wars often became increasingly hostile, leading to negative consequences for all combatants, as well as a broad and negative social consequence in the form of potentially misleading advertising.
\end{abstract}

\section{Keywords}

advertising history, marketing history, competition, advertising strategy

The historical research reported in this article examines the phenomenon of advertising warfare and what lessons have, or at least, might, be learned from advertisers' motives, successes, and failures. An advertising war occurs when one advertiser responds to a direct or implied attack by another. Both the original attack and the counterattack consist of comparative ads, those in which advertisers contrast their own products, services, or brands with those of a competitor on the basis of some attribute, benefit, market position, or brand image.

In the 1970s, the U.S. Federal Trade Commission (FTC) began encouraging advertisers to make comparisons with named competitors, with the broad, public welfare objective of creating more informative advertising. Although the widespread adoption of comparative advertising took a little longer in the European Community, Directive 97/55/EC (European Parliament and Council of the European Union) established that it should be permitted as long as, among other requirements, it wasn't anti-competitive, unfair, or misleading.

Industry lore suggests the use of comparative advertising was rare during the early twentieth century, at least among major advertisers. However, research indicates its use quickly increased in the United States. Researchers estimate that the overall percentage of comparative ads increased from about 7 percent (Shimp 1975; Wright and Barbour 1975) to 23 percent (Taschian and Slama 1984) to as high as 30 percent (Stewart and Furse 1986). Comparative advertising is more prevalent on $\mathrm{TV}$, with estimates ranging from 5 to 10 percent
(Brown and Jackson 1977) to 14 percent (Abrams 1982) to 50 percent (Levy 1987) to as high as 80 percent (Pechmann and Stewart 1990). There are no estimates, however, of the frequency of advertising wars.

Historian Daniel Pope (1983) identified three reasons why early advertisers condemned the use of comparative ads: (1) they were frequently false or misleading, (2) they "besmirched" the honor of advertising and damaged its credibility, and (3) advertisers preferred to avoid competing on the basis of price or other forms of business rivalry that could prove damaging to themselves as well as their competitors. However, he attributed these negative outcomes to comparative advertising in general and not to advertising wars.

The comparative advertising research literature is extensive, including several reviews (e.g., Barry 1993), a meta-analysis (Grewal et al. 1997), and a limited focus on negative comparative advertising (Beard 2008; James and Hensel 1991; Sorescu and Gelb 2000). Several surveys of practitioners are available (Barry and Tremblay 1975; Hisrich 1983; Muehling, Stem, and Raven 1989; Rogers and Williams 1989), although the findings

\footnotetext{
'Gaylord College of Journalism and Mass Communication, University of Oklahoma, Norman, OK, USA
}

\section{Corresponding Author:}

Fred Beard, 395 W. Lindsey, Norman, OK 73019, USA

Email: fbeard@ou.edu 
are limited by samples and response rates. Moreover, although there are signs the number of comparative advertising wars is on the rise in the first decade of the twenty-first century (York 2009), as well as lawsuits and National Advertising Division (NAD) complaints resulting from them (York and Zmuda 2010), there are no surveys of either marketing executives or advertising practitioners specifically on the topic of advertising wars.

Lacking from the literature, therefore, are many of the insights to be gained from studying those who have used advertising in open warfare. Thus, the purpose of the research reported in this article is to explore professional thought regarding comparative advertising wars. It seeks, in other words, explanations for why advertisers have chosen to go to war and what happened when they did. As Startt and Sloan $(1989,18)$ note, "Principles and problems, potential and pitfall can all be underscored by such knowledge."

\section{Research Questions and Data Collection}

The general advertising histories (Fox 1984; Laird 1998; Marchand 1985; Meyers 1984; Pope 1983; Presbrey 1929; Rowsome 1970; Schudson 1984) and the research literature devoted to comparative advertising were used during this study's immersion and guided entry phases. As described by Smith $(1989,319)$, "After immersion and consideration of the breadth of data available in a general area of interest, the researcher focuses on a more specific part of the data in a process called guided entry. ... In the process of guided entry, the historian further delimits the data to be studied and the process of general question forming begins."

The overall purpose of this study and the results of the immersion and guided entry phases led to the following research questions: What were the causes or motives behind decisions by advertisers to engage in sustained hostilities with one or more competitors? What were the marketing, professional, institutional, and other consequences, both positive and negative, resulting from advertising wars?

The collection of a database of professional thought regarding advertising warfare dating to the beginning of the twentieth century began with a search of the industry's foremost trade journal, Printers' Ink. Affectionately nicknamed The Little Schoolmaster by its editors and devoted readers, the journal was published continuously from 1888 to 1972 . Many articles published in Printers' Ink were written by advertising practitioners, marketing executives, and newspapermen, although the staff, including founder George Rowell, also contributed editorials and commentary.

One issue from each of the sixty volumes of Printers' Ink published between 1900 and 1913 was randomly selected and scanned because an index for this period does not exist. Sources for the remainder of the twentieth century through present day were then identified by means of a literature search, with the goal of collecting sources as equivalent as possible to those found in The Little Schoolmaster. This search was aided by the existence of three business periodical indices: the Industrial
Arts Index (1913-1957), the Business Periodicals Index (1958-1973), and the ABI/Inform Complete search engine (1971-2009). The Industrial Arts Index is the only business periodical index available for the period it covers; it continued in 1958 as the Business Periodicals Index. Some sources, in turn, revealed other sources, as well as the existence and location of comparative ads that represented attacks or counterattacks in advertising wars. Some of these are included in the findings, where they provide additional insight into the motives of the combatants, their tactics, or the consequences of an ongoing war. The research was conducted as part of a broader study of comparative advertising. Data collection produced a database of more than 600 trade journal articles on comparative advertising, of which some seventy specifically address sustained hostilities between two or more advertisers.

The method does not offer the appraisals of validity and reliability that quantitative content analysis does. It is consistent, however, with the methods of humanistic and empirical historical research. Defined by historian David Fischer, an empirical historian is one "who asks an open-ended question about past events and answers it with selected facts which are arranged in the form of an explanatory paradigm" (as cited in Smith 1989, 317). As Smith $(1989,317)$ elaborates, "The explanatory paradigm, of course, takes different forms - narrative, statistical explanation - but always consists of a reasoned, systematic examination of surviving recorded happenings, written in a spirit of critical inquiry seeking the whole truth."

\section{Findings}

Findings are presented chronologically, with the presence of dominant themes and subthemes supported by representative observations and statements of primary and secondary sources in each period. Contradictory themes are also presented whenever they occurred. The periodization scheme (Hollander et al. 2005) follows the lead of three important advertising histories (Fox 1984; Pollay 1985; Pope 1983) and for similar reasons. Modern advertising emerged and matured during the first three decades of the twentieth century. The Great Depression of the 1930s and war years of the 1940s substantially affected advertising spending and message strategy. The 1950s and 1960s are considered by many to be the golden age of advertising creativity and include the industry's much vaunted "Creative Revolution." The three earlier histories also discriminated between the 1960s and 1970s, although it is especially relevant for the present history because comparative advertising began in earnest in the United States during the 1970s. The final two decades are presented as a single period mainly for consistency.

Overall, the findings reveal that many well-publicized advertising wars occurred throughout the more than one hundred years represented by the data. A considerable degree of consistency exists regarding motives throughout the history. Outcomes and consequences, for the most part, also remain consistent, suggesting some validity in the observation of philosopher George Santayana (1905): "Those who cannot remember the past are condemned to repeat it." 


\section{The Turn of the Century to the Great Depression: Baking Powder Wars and Cigarette Wars}

Most advertisers early in the twentieth century claimed to disapprove of comparative advertising or what they often called "knocking" copy. As a Printers' Ink writer noted "In the early days of the art an advertisement was the voice of a single individual proclaiming the merits of his own goods, often coupled with a warning against similar goods sold by competitors. This one-man advertisement is still the commonest form of publicity, but among advertisers nowadays, the knocking of a competitor is considered not only bad form, but bad business" (Broad-gauge Advertising 1906, 30). Influential copywriter Claude Hopkins $(1930,20)$ spoke for many: "Rule 1 in all salesmanship courses I have studied is: Never attack a competitor." Concerns about the truthfulness of comparative price advertising also presented an early regulatory problem, attracting special scrutiny from the advertising practitioner "vigilance" committees, whose members stepped forward to carry the banner of the progressive "truth in advertising" movement of the 1910s (Pope 1983). Such statements, however, should not be taken to mean advertisers rarely attacked each other nor that they did not engage in warfare. The data reveal that several wars occurred during this period among, for example, the marketers of cigarettes, baking powder, automobiles, and tires.

Motives. Most advertisers or industry observers who wrote about advertising wars agreed that the decision to respond to an opponent's attack, rather than a strategically rational one, was often an emotional one, or one based on "human nature." A contributor describing a particularly vicious war between Calumet and the "Trust" baking powders summarized this belief: "It may seem strange that, where an advertiser has such direct evidence that straight promotion talk is the best thing for him, he should be persuaded to depart into the by-ways of competitive attack. The explanation lies in the fact that it is human nature to return a blow for a blow" (Hill 1910, 23). A San Francisco ad agency president in 1928 offered almost the identical observation: "But there is much of the peacock in many of us. We like to strut our insinuating advertisements up and down in front of our competitors. ... It is human nature - and when human nature runs contra to sound business judgment, our viewpoint is apt to be somewhat blurred" (Brisacher 1928, 161).

Several contributors during this period reported that wars often occurred when advertisers faced intense competition, explaining why advertisers of the day referred to comparative as "competitive" advertising. The term "comparative advertising," in fact, did not appear in the literature until 1931 and then infrequently until the 1970s. In reference to the Baking Powder War, an observer reported, "As competition began to show itself and as many new powders began to be offered at lower prices, the competitive and denunciatory style of copy was adopted" (Hill 1910, 24).

Several sources described the intense competition among cigarette marketers during the 1920s. Most linked the competition to combative advertising and, in particular, P. Lorillard's

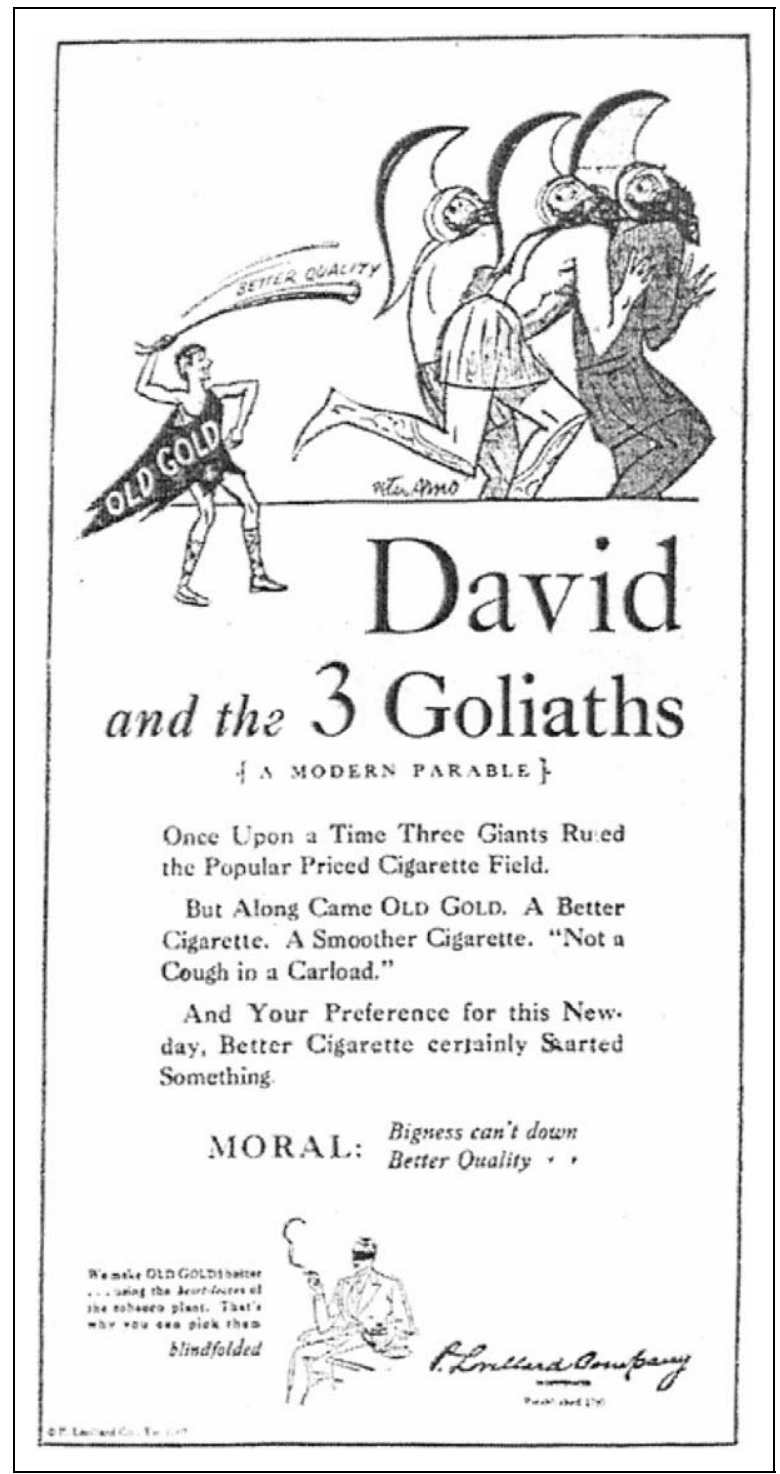

Figure I. Old gold "Goliaths," 1928.

forceful attempt to enter the market and steal sales from leaders Camel, Lucky Strike, and Chesterfield. At the time, these brands held nearly 75 percent of the U.S. market (Woods 1929). As Sales Management reported, "By 1928 all four companies were in the thick of an advertising melee such as has not often been witnessed. ... The retail price war, which broke out in 1928, added fury to the conflict" (How the "big four" cigarette advertisers stand in the 1929 sales battle 1929, 592). Another source directly attributed an attack by P. Lorillard to the intensity of the competition: "It is doubtful that competition within any other industry today could have brought forth the type of copy used by Old Gold.... The copy implied that Reynolds, Liggett \& Myers, and American Tobacco, the big three, jealous of Old Gold's success, sought to clip its wings by forcing wholesale price reductions upon it" (Lorillard goads big three in cigarette field 1928, 856). The sample shown in figure 1 clearly reveals the "David versus Goliath" theme of the campaign. 
That advertising wars often broke out when advertisers faced intense competition explains another finding. Some sources reported that advertising wars tended to occur simultaneously with price wars. For instance, the advertising and price wars that broke out among cigarette marketers in the 1920s was preceded by a similar one nearly three decades earlier. In his description of tobacco monopolist James Buchanan ("Buck") Duke's raid on the British tobacco industry and the ensuing advertising war, John S. Grey $(1902,16)$, a frequent contributor to Printers' Ink, reported, "The prices, too, are being cut, and the chances are that whichever party wins out at the end will be the loser anyhow, as the cutting process has already gone so far as to annihilate profits."

Consequences. Several writers and observers during this period strongly implied that many advertisers who engaged in open warfare came to regret it. Two related consequences help explain this regret. First, observers reported a tendency for hostilities to escalate, with claims on either side becoming increasingly vicious (or what they called "invidious"). As an agency president wrote, "The average advertiser who casts insinuations at competitors usually soon finds the weaknesses of his own products alluded to in his competitors' advertising. Few, if any, products are made so perfectly that certain weaknesses cannot be found and perhaps exaggerated to such an extent that they will prove both embarrassing and harmful" (Brisacher 1928, 167). Following George Washington Hill's attack on the "sweets" industry ("Reach for a Lucky Instead of a Sweet"), a chain of candy stores counterattacked with this warning: "Do not let anyone tell you that a cigarette can take the place of a piece of candy. The cigarette will inflame your tonsils, poison with nicotine every organ of your body and dry up your blood - nails in your coffin" (as cited in Lucky Strike and the candy industry mobilize for battle 1928, 10).

A second and related consequence, also explaining regret, was the tendency for the escalation of hostilities to cause damage to both combatants. One type of damage was to the reputations of the advertisers and their brands. Writing about George Washington Hill's war on the sweets industry, the president of the New York Coffee and Sugar Exchange Inc., observed, "Has Mr. Hill forgotten that it was only a short time ago when some of our states, on health grounds, were legislating against cigarettes and that the term 'coffin nails' was applied to them? Would it not be well for the American Tobacco Company to 'Let sleeping dogs lie?'” (Lowry 1929, 790). A Printers' Ink author many years after the Baking Powder War warned that this kind of damage could last for years: "Lots of people still alive and well can vividly recall the days of some years ago when they were repeatedly warned to beware of 'benzoate of soda.' ... Eventually, the various manufacturers and advertisers of foods discovered the alarming effect such copy was having on their business, and they recovered their reason by stopping all such publicity" (Hanley 1927, 10).

Advertisers and observers who addressed the strategic value of a war consistently noted the tendency for combatants to lose focus on their own selling. George Washington Hill summarized this belief in his reference to his confectionary opponents: "If they would forget about our campaign and devote themselves to making their own merchandising interesting and constructive, they would never have occasion to complain. When you start worrying about the other fellow's business you cease to sell your own merchandise" (as cited in Hughes 1929, 401).

Some advertisers during this period expressed the belief that consumers tend to respond negatively to advertising wars. As one noted, "Isn't the public suspicious of sweeping claims of superiority and allegations that no one except the advertiser himself should be credited with common honesty? Isn't it human nature to take the part of the underdog and to resent a holier-than-thou attitude?" (Hill 1910, 25). In early 1930, R. J. Reynolds directed figure 2's aggressive attack on Hill and American Tobacco, after the FTC had ordered Hill to cease using "tainted" testimonials and making the claim that "Luckies" would help smokers lose weight. Claude Hopkins $(1930,20)$ argued that consumers would respond negatively to Reynolds's opportunistic attack: "Some methods strike a responsive chord which lead to overwhelming favor. Some arouse dislike. I hope that George Hill will not take up the gauntlet Camel has laid. I think that a shiver went over all of us when we read that page attack."

Only a single source attributed positive consequences to an advertising war. An anonymous banking executive described his view of Hill's attack on sweets, arguing that both sides as well as consumers could benefit: "Even the public at large may derive advantages sufficient to justify the cost, it is contended, since such advertising brings out values in products that have never been generally known. This type of sales effort helps to make the public the real arbiter of what it shall buy; and, if properly weighed, tends to raise the level of intelligence upon which demand and consumption are based" (What a bank thinks of the cigarette-sweets war 1929, 101).

\section{The Great Depression and the War Years: The "Dirty Laundry Effect"}

Advertisers and industry observers who wrote about advertising wars during the 1930s revealed the occurrence of numerous wars between major competitors, among them tires, automobiles, gelatins, salad dressing versus mayonnaise, coal versus natural gas heating, iceboxes versus mechanical refrigerators, and even Florida versus California orange growers. Beard and Nye (2010) found that, by the early 1930s, publishers were agreeing unanimously that comparative advertising had become a serious regulatory problem, often requiring rejection of ads. However, only a few sources discussed advertising wars in the 1940s, possibly a consequence of large reductions in advertising spending during World War II and an expanding economy, product shortages, and a seller's market at the end of the decade.

Motives. The belief that it was "human nature" to launch a counterattack was prevalent during the 1930s. Ralph Star 


\section{Turning the light of Truth}

on false and misleading statements in recent cigarette advertising

W HAT PTOTHER MANUFACTURER OF eigarettes chiooses to say about his product is not our affair. Even when he sees fit to misrepresent his product and leave false Impressions concerning it, that still is his buslness - not ours.

But-when, in his advertising, he goes beyond his own product and makes false state ments or leaves misleading Impressions about other cigarettes - then it is time that the truth be told.

Some time ago a manufacturer of eigarettes used the following statements in his advertising

"Thio extra secret heating process removen from (- ) harmfal irritants, corrosive acride, which are present in elgarettes manu. factured in the old-fanhloned way, and which faetured in the olddanhioned way, and eanse throat irritatioa and coughing"
"No matter how mueh or how little you pay for elgarettes you have a choice of only two general elasses, and not more than two. In one elass you have the billions of cigarettes mennfactured in the old-fachioned way and in the other clan yon have ((n) the coasted cigarette, a product of modern ocience, a elgarette from which harmful irritants have benen removed by that extre secret process described by the phrase 'I', Tousted?"

TV HEN THESE STATEMENTs were first Wade, we assumed that they were a casual phase of that manufacturer's advertisIng and did not represent a deliberate and calculated policy. After making a few such statements, he abandoned this particular form of advertising. However, other stato ments used in his advertising came to the attention of the Federal Trade Commission ga a question of thelr truthfulness.
Ts a result of the aetion of the Federal Trade Commission he was ordered to stop his acuraitted praetice of using in his advertising falso testimonials of non-smokers to the effeet that they kept slender by smoking his brand of elgarettes, and was further ordered to stop using other fake testimonials and the specious argument that all can keep slender by smok. ing that brand of cigarettes. He then began to we again the form of statement quoted above or pariations of it.

TF XNY MANUFACTURER chooses to say that I the tobaccos he uses contain "harmful irritants, corrosive acrids, that are injurious to the throat," and then to claim that these things are removed by the heat-treating process, that is his own affair. But when he tries to create the impression that it is general practio, to use in eigarettes sueh rank tobaceos as he describes, wo object to the attempted reflection on the industry.

We have never used in our blend those rank tobaccos which can be properly described as containing "harmful irritants, con rosive acrids," nor do we believe that they are used by, some of the other manufacturers.

If that manufacturer wishes to advertise heat treatment, calling it toasting or what-not, that is his right. But when, in so doing, he tries to create the impression that he is the only maker of eigarettes who treats tobaceos with heat, the truth again needs to be told.

Tho publication of a fake testimonial is no greater perversion of the truth than to imply final the Feiat treatment of tobaceos ls an exclu. sive process with any single manufacturer.

7 TEE FACT is that the use of Geat treatment $I_{\text {in the manufacture of tobaceo is aboul }}$ the most commonplace and universally praco. ticed method in the industry. It has long been standard practice.

Wo use heat treatment in Ifs most modern and scientific application, both in the preparation and in the manufacture of those mild, fragrant, ripe tobaccos that carry their nat. ural goodness into CAMEIS.

The first CAMrL Cigarette we ever made was manufactured under the heat-treating process. Every one of the billions of CAMEIS produced since has been manufactured under heat treatment. We rely upon heat to the limits of its possibilities to make our good tobaceos better. It cannot make inferior tobaccos good.

WTHETHER OR NOT a manufacturer, to W have something to talk to the publie about, attaches a contrivance to his heat-treal. ing machines to catch, condense and bottlo the vapors that come from them can have no more effect toward improving the tobaceo than your eatching and bottling the vapors that come from your teapot would have toward improving the tea in the pot.

Our own brand, CAMEL, continues to grow, but we are, nevertheless, unwilling to le! these far-reaching false statements or im. pressions regarding the cigarette industry go uncorrected.

\section{R. J. Reynolds Tobacco Company Makers of CAMEL Cigarettes}

Figure 2. R. J. Reynolds Attack, 1930 (Credit: R. J. Reynolds). 
Butler (1931, 105), an advertising pioneer and author of the first textbook on marketing, summarized the view of the majority: "Human nature being what it is, there comes a time when fighting back seems to be the only recourse of the advertiser who has tried to do business on a constructive basis." As another writer observed, "It is an understandable temptation for any dealer selling in a given community to strike vigorously at competition which he regards as unfair. ... Yet, it is a fact of human nature that, however right he may be in his thinking, he must be careful how he calls such a condition to the attention of the community" (Copy should avoid criticism of competitors 1936, 83).

Two additional motives were mentioned during this period but by only two sources. The first is that advertisers often respond to attacks because they enjoy a fight. Writing about the advertising war between California and Florida orange growers, Business Week observed, "Much as they may publicly deplore the violence done professional ethics, advertising men privately relish nothing more than a juicy competitive copy fight" (Califlorida orange growers fight $1937,21)$. The second, that wars can occur inadvertently, was stated by long-time Printers' Ink editor C. B. Larrabee (1934, 57): "Some smart young advertising man gets what is known in the trade as a 'swell idea.' ... Too frequently such an idea is loaded with dynamite because it will almost inevitably lead to a competitive war."

That intense competition often leads to warfare was mentioned by industry leader Joel Benton, then president of the American Association of Advertising Agencies, in a lecture to the feuding tire industry. Benton $(1932,55)$ also proposed that advertisers may engage in warfare as a defensive response: "They can do little by themselves; they are in the grip of a relentless competition which sets the pace; if their opponents fool the public with false offers and slurring statements, they feel they cannot afford to let the culprits get away with it and so do likewise."

Consequences. Several sources again argued that hostilities can escalate, often leading to exaggerated claims. In his description of a war between manufacturers of refrigerators and increasingly obsolete iceboxes, editor Larrabee (1934, 58) noted that during a war an advertiser often "directly points the finger at competing products and says that they are of no value - or even harmful. Once a company commences a competitive campaign of this kind it is in for a long battle with other companies in its industry." Indeed, exaggerated claims characterized one of the period's most contentious wars. In late 1937, California orange growers attacked their Florida competitors with the dubious claim that the juice of their oranges was "22\% Richer."

Printers' Ink identified the "dirty laundry effect" by name in its description of a war between Royal and Knox gelatins, after the former used "gelatine smell" in a disparaging attack. "If the battle of the coffees, which started when Chase \& Sanborn, another product of Standard Brands which owns Royal, is any guide, the consumer is in for some unpleasant

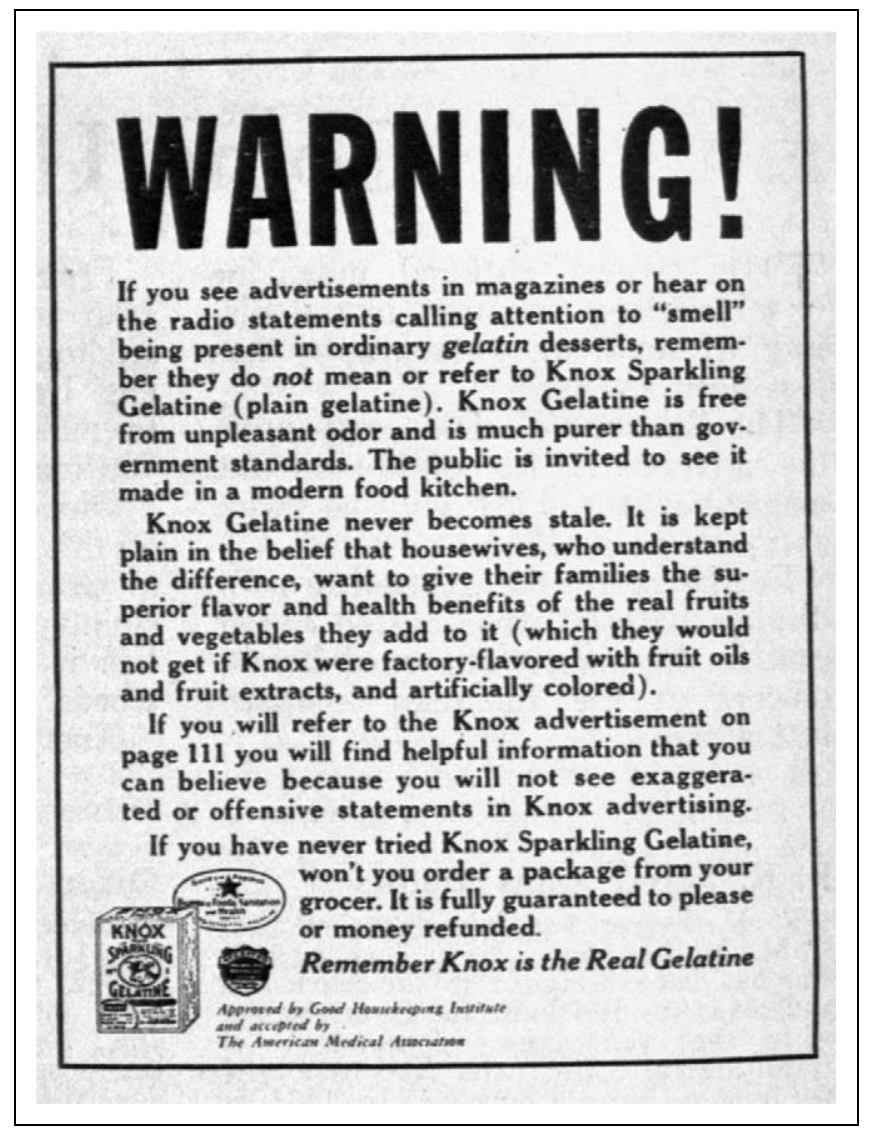

Figure 3. Knox “Warning,” 1934.

months as she watches national manufacturers, forced into competitive tactics, washing their linen in full view of the public" (Knox fights back 1934, 18). Knox actually warned consumers about exaggerations in advertising and promised they would not do it themselves (see figure 3).

Some contributors during this period also expressed the belief that wars could lead to damage for both sides. An agency executive summarized this view: "And what does the old advertiser do defensively - the obvious come-back, to our disappointment, with an attack that imputes the basic quality of the competitive product. And they both must suffer in consequence, as such competitive claims can only substitute doubt for confidence in the public mind. How unnecessary, wasteful and foolish!" (Tinsman 1941, 64). A Printers' Ink author stated the theme even more directly: "But when one party says one thing and the other states what seems to be a directly conflicting fact, the likely conclusion of the consumer is that one of the two is a liar-probably both" (Erbes 1934, 46).

Several contributors noted that combatants often became so preoccupied with attacks that they forgot to sell their own products. Printers' Ink columnist George Laflin Miller, who wrote for decades under the pen name "Aesop Glim," summarized this view: "The temptation is to try to do or say something your competitor has never said. The further you go along this path, the greater the danger that you will stop using your basic sales arguments" (Competitive or positive; Aesop Glim 1947, 76). 


\section{Let's have a SHOWDOWN on this matter of TIRE COMPARISONS}

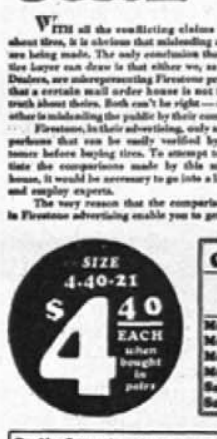

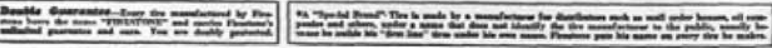

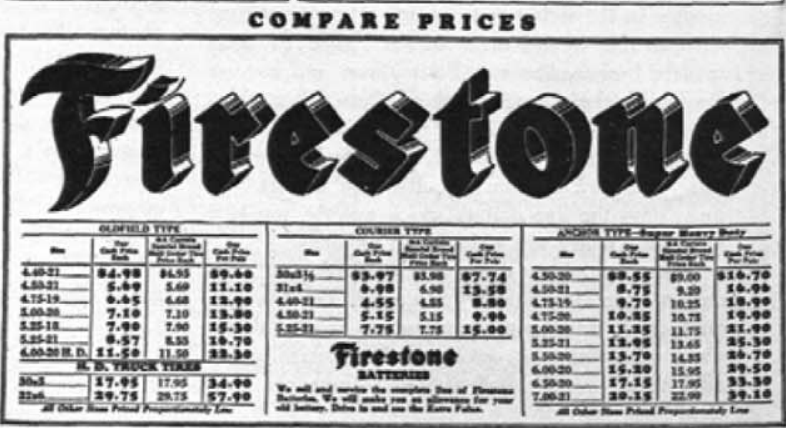

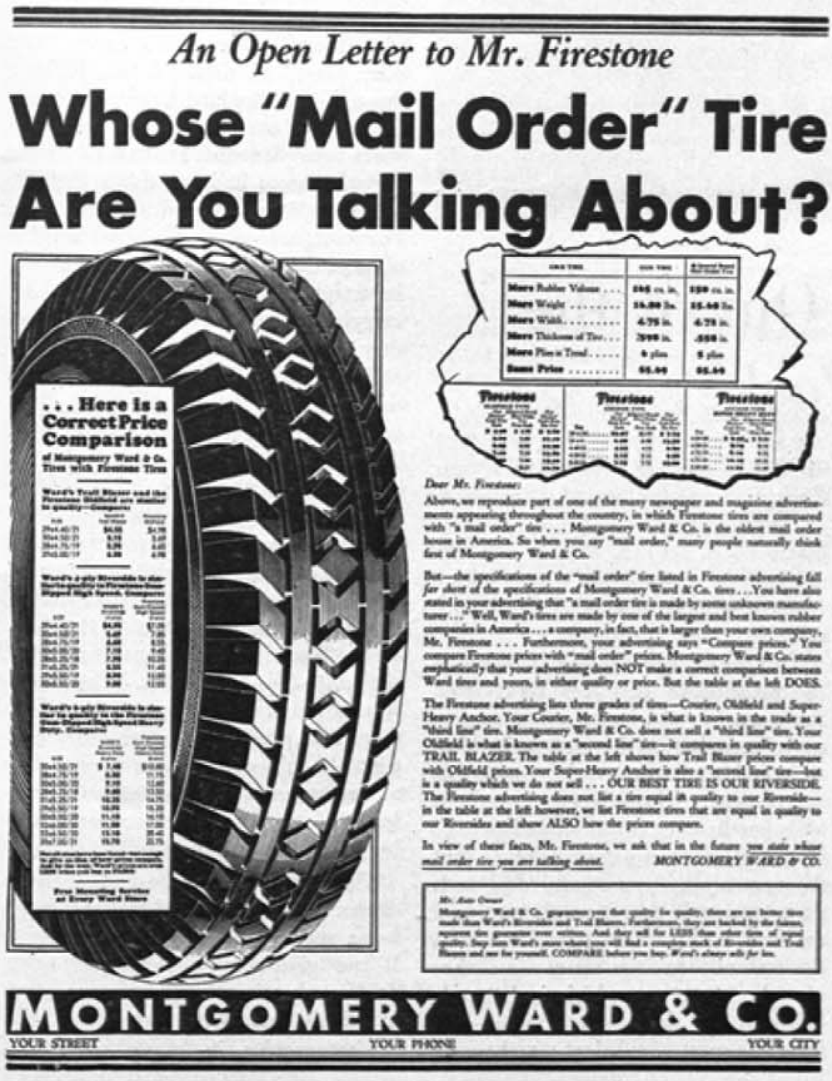

Figure 4. Firestone and Montgomery Ward at War, 1931.

Writing about the advertising war between U.S. automakers, an observer similarly noted that "The participants are so apt to become absorbed in strategy that they forget that their principal job, after all, is to sell automobiles" (Round Four; Chevrolet lands a blow on Ford in the three-cornered automobile fight 1933, 12).

Although one writer claimed that advertising wars often led to "the great glee of the purveyors of white space" (Word War; mayonnaise and salad dressing, steel and steel-wood motor bodies are arguing in public 1933,21 ), the majority agreed that wars create problems for the media, leading to what advertisers simply referred to as "censorship." An observer of the Tire Wars noted, "How do the publishers - who in the last analysis are in the best position to censor advertising-look upon this competitive copy? Askance, undoubtedly, but they take it" (Tires throwing mud 1931, 21). A publisher, writing anonymously about the problems created by advertising wars, lamented, " . . must the publisher always be the one to play the part of the wet nurse? Must the publisher always be the one to suffer when a couple of advertising prima donnas start tearing at each other's hair?" (Prima donnas at war 1937, 17).

During the early 1930s, Montgomery Ward \& Co., Sears, Roebuck \& Co., and Firestone Tire \& Rubber Co., were among several companies that fought a war over replacement automobile tires. Since attacks published in their own catalogs could not be censored, Montgomery Ward and Sears both compared their private brand tires by name with those of competitors. As the only one of the big five U.S. manufacturers who did not make private brand tires, Harvey Firestone counterattacked (see figure 4). Despite not directly identifying his mail-order foes, many newspapers rejected the ads. Montgomery Ward returned fire on Firestone (see figure 4) and, simultaneously, filed a complaint with the FTC against comparative tire advertising and directed at, as one source noted, "obviously that of the Firestone Tire \& Rubber Co." (Comparisons become invidious in rivalry for tire market 1931,9$)$.

Sources during this period made numerous references to how consumers respond to advertising wars. When they did, the majority pointed to two likely consequences. First, they noted that wars often led to confusion. Describing the war among the Big Three U.S. automakers, Printers' Ink summarized this belief: "After reading the contradictory facts and figures, many a prospective automobile buyer must have decided to follow Ed Wynn's advice and buy a horse" (So he bought a horse 1933, 10). Second, contributors consistently argued that consumers rarely respond positively to advertising wars. Writing about the Cigarette Wars, an advertising executive noted, "Meanwhile the rather reasonable impression is gaining 
ground that the American people do not care a Hannah Cook about the private quarrels of advertisers ..." (When you knock your competitor you knock advertising! 1931, 18). Referring to an advertising war between coal and heating oil distributors, a Printers' Ink author similarly observed, “... such a battle would no doubt result in a condition of the buyers of these fuels having about as much confidence in their distributors as the average layman has in our politicians of the present day, who have been practitioners of such tactics for a long time and are esteemed accordingly by Mr. Average Voter" (Erbes 1934, 81).

As during the previous period, there were almost no positive consequences attributed to an advertising war, with one Depression-era exception:

\footnotetext{
... it is probably true that Mr. Average Tire-Buyer is more interested - especially in this year of hard times - in price comparisons than he is in the word-sparring of the contestants. Consequently, this advertising may be selling him more tires simply because it is telling him more forcibly than ever before at how low a price tires can be bought. Firestone claims that this is the case, that sales are mounting because the public had no idea a tire-a Firestone tire, mind you - could be bought so cheaply (Tires throwing mud 1931, 21).
}

Finally, the first proposal appeared regarding how advertisers should respond to attacks. Printers' Ink praised Knox for not airing dirty laundry in its counterattack. As the journal noted, "It is significant, perhaps, that Knox wisely has not interrupted as yet the even tenor of its advertising. Its 'Warning' is extra space taken with the sole purpose of fighting back and the washing of linen in the regular campaign is noticeable by its absence" (Knox fights back 1934, 19).

\section{The 1950s and 1960s: Avis Tries Harder}

Trade articles on advertising wars were infrequent during this period, even though a major industry and regulatory scandal occurred over fictitious comparative price advertising during the 1950s. In addition, not only were advertisers growing increasingly competitive in their advertising toward the end of the $1960 \mathrm{~s}$, comparative advertising became a major regulatory headache for the TV networks (Beard and Nye 2010). Sources for this period confirm the occurrence of several wars between, for instance, toothpastes, margarine and butter, rental cars, cigarettes, automobiles, and razors. Most important, the early 1960s saw a war that many agree established the modern era of comparative advertising-Avis Inc. versus Hertz Corporation. Although it took several years for Hertz to counterattack, and their early rejection of this strategy led to an advertising agency change, they ultimately did with the following copy: "For years, Avis has been telling you Hertz is No. 1. Now we're going to tell you 'why.",

Motives. Few sources mentioned motives for engaging in advertising wars but those that did reaffirmed the earlier belief that the decision was rarely arrived at rationally. Writing metaphorically about an advertising war between two hypothetical paint companies, an NBC network radio sales promotion manager and freelance writer noted that "Asserting that you are the leader in your field is probably good for your ego-if your ego is the kind that requires such assertion" (Ecclesine 1950, 66). An American Dairy Association executive, explaining the decision to declare war on margarine marketers, declared he was "fighting mad and ready to slug it out with the makers of that lower-price spread. ... They've been rough with us, such as calling us that higher-price spread, and we've had enough" (as cited in ADA ads aim to tweak conscience of oleo buyers 1959, 8).

The likelihood that intense competition encourages a war was also evident in this period, with the sole reference to it suggesting that increasing sales and limited competition would reduce the odds of a counterattack. After Rambler launched attacks against the "gas-guzzling monsters" of Chevrolet, Ford, and Chrysler, a writer argued that it was unlikely they would reply because all three were " ... enjoying higher sales than at this time last year, and may simply let well enough alone" (Rambler taunts trio of rivals in new ad 1959, 12).

Consequences. Several sources in this period again pointed to the potential for wars to escalate and lead to exaggerated, mean-spirited, and often misleading claims. Describing a 3-year war between Bostitch and 3M over the superiority of packaging tape versus staples, a writer noted it included ads many criticized, "such as one of a worker opening a stapled carton and holding up a blood-soaked finger with a staple hanging from it," or that they "presented competing closure methods in an unfavorable light-for example, by not picturing the proper instruments used in that method" (How ethics inspired an ad treaty 1961, 38). An agency executive with 40-years experience similarly criticized one of Hertz's counterattacks: "As so often happens when you concentrate on competitive experiments, the zeal of combat led this company into an ad which many people believe hit below the belt: 'Avis can't afford television commercials, aren't you glad?' is the headline..."' (Advertising: A bare-knuckle brawl 1964, 58).

Kenneth B. Willson, then president of the National Better Business Bureau, made the point directly: "Exaggeration by one 'knocking' advertiser leads to further exaggeration by his competitors and eventually to outright misrepresentation. ... As exaggerated competitive claims or half-truths are hurled by scores of business rivals, none will have any effect at all on any but the small unthinking part of the public" (as cited in Christopher 1965, 79).

The beliefs that consumers respond negatively to wars and that they can lead to damage to both parties were again expressed by numerous sources. In a speech to the Advertising Club of Greater Boston, David C. Stewart, president of agency Kenyon \& Eckhardt, summarized this belief: "There are certain industries and certain product areas today in which the battle of competitive advertising claims has reached the harsh crescendo of jungle warfare ... public confidence [once] 
shaken ... [usually exerts] a stern reaction against the industries themselves" (as cited in Overly competitive ads invite action by U.S. 1965, 68).

Notably, not a single contributor directly attributed positive outcomes to a war during this period. However, one source did argue the possibility that both sides might benefit. "Hertz absorbed the Avis blitz for quite some time and then came out with a campaign of its own, stating the whole thing was little more than a mosquito bite, and, in fact, saying that the Avis barbs actually helped Hertz business. Perhaps the whole controversy will end with that ironic discovery" (Just a mosquito bite 1966, 78).

\section{The 1970s to 1980s: Pepsi Challenges}

The use of comparative advertising in the United States expanded during the 1970s. Not only did the FTC ask the TV networks in early 1972 to agree to a 1-year trial of comparative advertising, the agency actually threatened industry groups with legal action if they did not strike down codes and selfregulation policies that limited or forbade comparisons with named competitors. In 1982, the National Association of Broadcasters (NAB) was targeted by a U.S. Justice Department anti-trust lawsuit. Although the legality of the comparative advertising codes was not questioned, the NAB settled by suspending all code enforcement. Consequently, wars broke out in many product categories, including soft drinks, analgesics, fast food, spaghetti sauces, household cleaners, razors, and California wines.

Motives. Only three sources directly addressed the motives behind an advertising war during this period; again, two of them acknowledged the emotional theme. Writing about the evolution of comparative advertising law, an attorney warned advertisers to avoid attacking competitors: "When a competitor's name is used, its temperature goes up and there is a greater likelihood of a lawsuit" (Meyerowitz 1985, 84). The author of a regular column in Direct Marketing similarly observed, "Sure, it feels good to get your feelings about your competition off your chest. But if your attack results in a poor response, that's a pretty high price to pay for feeling good" (Brock 1982, 93).

The third contributor, an Advertising Age reporter, described two related motives referenced in earlier periods. First, and writing about the war between Procter \& Gamble's Scope and Warner-Lambert's Listerine, she noted, "Listerine, the company said, turned to name-calling as a last resort to defend itself" (Giges 1980b, 64). Second, she suggested there might be a growing reluctance among advertisers to engage in wars in the first place. Referring to the outbreak of the first Cola War, Giges $(1977,35)$ reported, "The signal to go after Pepsi was eventually given by Coca-Cola's top management after much soul-searching and speculation about what could happen if a Pepsi national rollout had a major impact on consumers."

The effects of intense competition were also quite evident during this period; some sources, however, linked it directly to sales declines on the part of the combatant initiating the aggression. For instance, 'Lurking behind Ragu Foods' complaints about Campbell Soup Co.'s comparative ads for Prego spaghetti sauce is a slow but sure drop in Ragu's market share. And ... the company is considering 'alternative' ad approaches for fall [which could] ... make way for a comparative counterattack against Prego" (Dagnoli 1989, 4). The effects of slow growth and sales declines were also evident at the outset of the Burger Wars. As reported by one source: "Desperate to resuscitate its growth momentum, Burger King Corp. is hitching its company fortunes to a massive comparative marketing campaign, replete with 'Pepsi challenge'-style taste-test research..." (Kreisman and Marshall 1982, 1).

A competitor's entrance into a market sparked one of the most infamous advertising wars of this or any other period. When Johnson \& Johnson subsidiary McNeil Laboratories learned Bristol-Myers would launch Datril at a lower price and with a comparative attack, the company invested $\$ 20$ million to send out 700 "detail men" to mark down every Tylenol package they could find. The goal was to nullify the Datril price claim before the attack was launched. It is also important to note that the price-comparison advertising war that ensued provided direct support for the FTC's campaign to encourage comparative advertising and discourage self-regulation policies against it, such as those of the NAB and the NAD. As a source at the time noted, "The fact that J\&J immediately cut the price of Tylenol in the face of competition from Datril is bound to catch the attention of anti-trusters at FTC and the Department of Justice ... " (J \& J slashes Tylenol's price, objects to Datril ad approach ... 1975, 1).

Consequences. The belief that hostilities often escalate was also evident during this period. Agency Ogilvy \& Mather's chairman Andrew Kershaw $(1976,26)$ summarized this view: "We have already seen that ferocious hostility erupts between corporations that used to be sensible, honorable competitorsall because of some stupidly provocative advertising." As Johnson \& Johnson and Bristol-Myers battled over the nonaspirin market, Sterling Drug sought to slow Bayer Aspirin's steep decline in sales with the extraordinary attack shown in figure 5. As an Advertising Age writer noted, "The copy scolded the maker of Tylenol for trying to mislead consumers in making the claim, 'Why doctors recommend Tylenol more than all leading aspirin brands combined" (Giges 1980a, 66).

Some sources, as in earlier periods, noted that combatants often lost focus on their own selling points. A Coca-Cola bottler spoke for many: "I've always felt the best way to sell is to try and communicate why consumers should buy your goods and not why they shouldn't buy your competitor's..." (as cited in Giges 1977, 35). A Burger King executive also mentioned the problem of losing focus, even when referring to what was widely considered a victory in the opening battle of the Burger Wars: "It's very easy to get off track. You can get so caught up in competition that you forget the positioning", (Comparative ads paying off 1984, 18). 


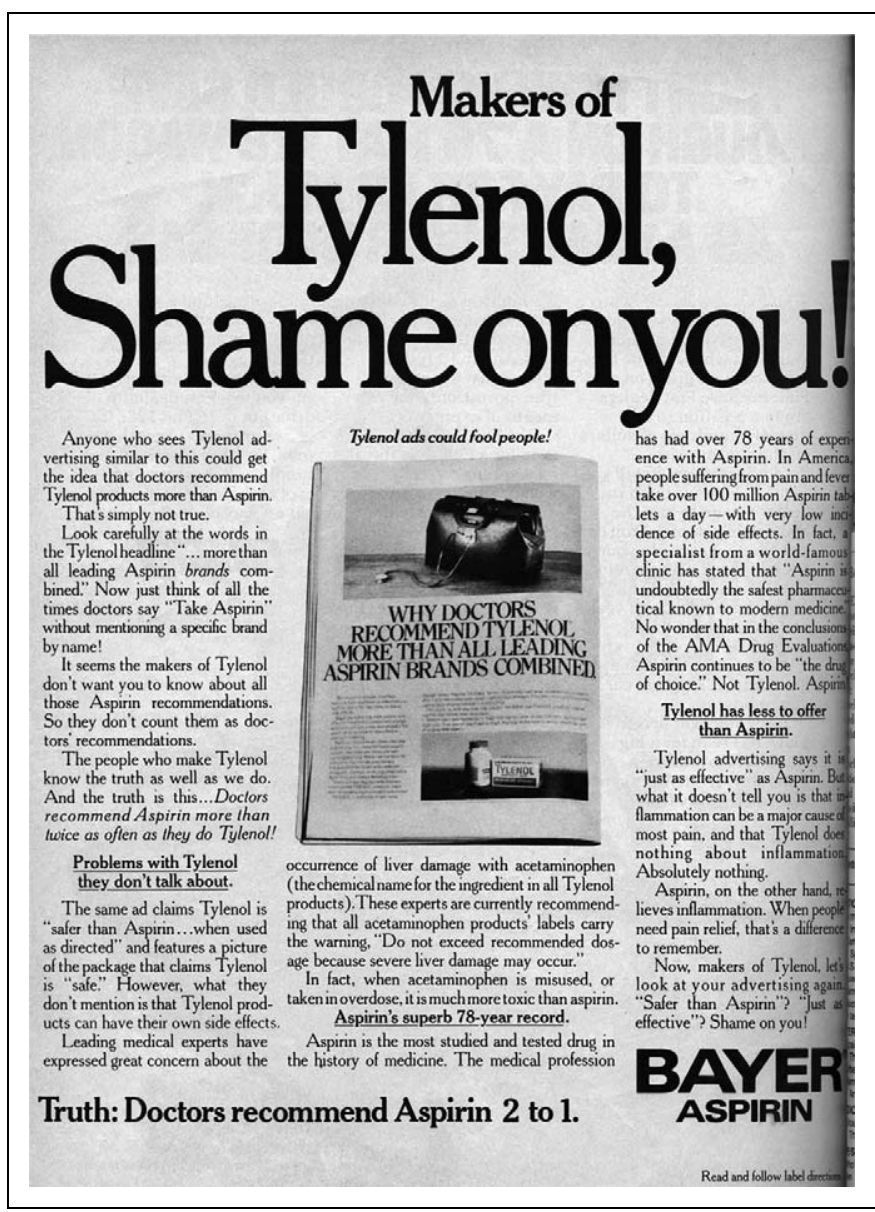

Figure 5. Bayer Aspirin's attack on Tylenol, 1980.

A Coca-Cola executive mentioned the tendency for both sides of a war to suffer damage. He told Advertising Age that he called a ceasefire because comparisons based on "highly subjective areas ... can only work to the detriment of the industry" (as cited in Giges 1977, 32). Comparing the likely consequences to an earlier decline in coffee consumptionafter coffee marketers "thought it would be smart to turn inside and begin feeding upon each other"- - he warned executives and bottlers: "We must never forget that the real competition facing soft drinks is, first, and foremost, other types of liquid refreshment" (as cited in Giges 1977, 32). Somewhat ironically, although Pepsi claimed victory in the Pepsi-Challenge inspired Cola War, "Unofficially, even Pepsi sources acknowledged that drastic discounting and counter moves by Coke clouded campaign results" (Giges 1980b, 59).

"Father of motivational research" Ernest Dichter warned that consumers often respond negatively and with confusion to advertising wars. As Dichter $(1977,8)$ told the members of the American Marketing Association: "The more confusing and vicious the mutual attacks become, the more the respondent comes to the conclusion that he had better rely on his own judgment and not on what he is being told in the ad." Agency BBDO pointed out that the smaller competitor, the "underdog," tends to benefit from an advertising war because "The American housewife ... can be alienated by what she feels to be an unfair attack on one of her favorite products" (as cited in Underdog advertiser wins in "naming names:" BBDO 1975, 1).

Two additional consequences found expression during this period. First, a few sources agreed with agency Ogilvy \& Mather that both sides of a war may benefit. Consistent with this belief, a McNeil marketing executive said the company "does not feel the Datril advertising has been detrimental to Tylenol. The company is now shipping all the products it can make, and the ads have had the effect of acquainting consumers with Tylenol as well as Datril ..." (as cited in Giges 1975, 61). Second, after Burger King agreed to an out-of-court settlement with McDonald's Corporation and Wendy's International, the executive who ordered the attack praised its publicity value. He told Advertising Age that the media attention alone may have been worth as much as $\$ 20$ million in added sales (as cited in Moran 1984).

Several successful tactics for responding to attacks were mentioned during this period. For instance, Cola-Cola used brand Fresca as a "stalking horse" in one of its first responses to the Pepsi Challenge (Giges 1977). The stalking horse is an exercise in misdirection and risk assessment. A surrogate is used to launch an attack-in this case, Fresca, rather than the Coca-Cola flagship brand - to assess the likelihood of success or failure. Second, in another indirect counterattack, Coca-Cola responded with a campaign designed to disparage Pepsi's tastetest advertising. A Coca-Cola executive explained to Advertising Age: "We felt like we weren't really knocking Pepsi, which we didn't want to do, but we were knocking the technique an advertiser was using - and that advertiser just happened to be our competitor, Pepsi" (as cited in Giges 1977, 75).

A third strategy was demonstrated in a response to a Business Week magazine attack on the Wall Street Journal. The ad in question had shown the Journal stuffed in a wastepaper basket and implied that the Friday issue had little value. Rather than respond directly, the Journal " ... retaliated in a low-key way. It ran a spread ad in the March 22 issue of Advertising Age showing a backseat rider in a Rolls-Royce asking: 'Did you see that story in Friday's Journal?' Although it made the point that the Journal was 'top-of-the-day reading every business day,' it especially touted the Friday Journal as a wrap-up of the week's events" (Emmrich 1982, M6). Finally, as advertising wars broke out among financial institutions during this period of recession, bank failures, and deregulation, one marketing manager chose not to "slam an ad into the media" in response to a competitor's claim to pay the highest rate of return on IRAs (Individual Retirement Account) (Case of the IRA affair $1985,11)$ but instead gave frontline representatives additional training to explain the differences in the investment programs to customers on a one-on-one basis.

\section{The 1990s to 2000s: Credit Card Wars, Beer Wars, and a Pizza War}

Although the data do not lend themselves to quantitative analysis, it seems likely that advertising wars have been more 
frequent during this period than any other. Several wars carried over from the 1980s (e.g., the Analgesic Wars, Burger Wars, and Credit Card Wars) and many new ones broke out in industries such as cell phone services, computer hardware and software, pizza, brewing, batteries, satellite TV services, coffee, condensed and ready-to-eat soups, and sports drinks, to name just a few. As in the beginning, many advertisers condemned attack advertising. A Microsoft executive captured the view of many: "I don't think there's ever been a study that shows that negative advertising sells products" (as cited in Jaben 1992, 3).

Motives. As in previous periods, sources either implied or stated directly that the decision to respond to an attack was often an emotional, rather than a rational, one. Referring to the Credit Card Wars, an Advertising Age writer noted, "Some analysts say the efforts are better at soothing CEOs" egos than swaying public opinion" (Levin 1994, 4). In the Long-Distance War, an Adweek writer reported that "Neither AT\&T nor MCI were running ads for consumers; instead, they were targeting each other's boardrooms. ... They were meant to get the other guy's goat" (Benezra 1998, 46). In reference to the Soup War between General Mills (Progresso) and Campbell Soup (Select Harvest), James P. Othmer (author of Adland: Searching for the Meaning of Life on a Branded Planet) told The New York Times: "They're navel-gazing and they're not thinking about what consumers want to hear-they're just talking at conference tables about how to strike back or how their integrity has been affected" (as cited in Clifford 2009, A1).

The effects of intense competition were clearly apparent in the description of nearly every advertising war that occurred during this period. Moreover, and as reported during earlier periods, counterattacks were sometimes motivated by the perception that advertisers needed to defend themselves. An observer of the Long-Distance War offered an example: "Ma Bell [AT\&T] tried to ignore MCI's nonstop attacks, but its competitor's blows were clearly drawing blood" (Benezra 1998, 46). Similarly, another source proposed that after Visa USA invested millions of dollars in an official Olympic sponsorship, the company was forced to respond to American Express ambush advertising: "The Visa-American Express standoff is a bit testy, the public display of a bitter behind-the-scenes battle in which Visa is fighting to protect its investment" (Davidson 1996, 11). A Pizza Hut executive summarized the thinking behind this motive succinctly: "If you want to call it aggressive, that's your decision. We feel we have to take remedial action to set the record straight with consumers" (as cited in Kramer 1999, 4).

Consequences. Several sources also noted the tendency for advertisers to regret becoming involved in advertising wars. No one, however, throughout the 100 years of data analyzed for this study summarized the theme of regret as clearly and colorfully as a soldier in the Spaghetti Sauce War: "between [Unilever and Campbell], we're spending $\$ 60$ million a year to convince consumers that our spaghetti sauce is really crappy" (as cited in Neff 1999, 26).
The belief that advertising wars tend to escalate was also evident in this final period, with many specific examples. In late 1994, for instance, the attacks and counterattacks between Visa USA and American Express Co. became increasingly hostile, following American Express's launch of its Optima True Grace card. After the card was launched with the promise there would be no interest charges during the grace period, Visa USA fired the salvo in figure 6. Within days, American Express replied with a counterattack, also shown in figure 6 , including the satiric "Visa. It's everywhere you want to pay more interest charges." The rush to counterattack may help explain why American Express failed to identify itself in its own full-page newspaper ad.

In the Beer Wars, which continue today between AnheuserBusch and Miller Brewing, combatants often turned their attacks to the quality of opponents' products. In one of the most infamous examples, Anheuser-Busch ran commercials criticizing Coors Brewing Co. for diluting its "pure Rocky Mountain Spring Water" with local water, once the Coors Light concentrate reached Northeastern markets. Two years later, AnheuserBusch launched an almost identical attack on Boston Beer Company, with a campaign revealing that Sam Adams was regionally brewed by other brewers under contract. In perhaps one of the most juvenile examples of the theme of hostility escalation, during a spring 2009 broadcast of "American Idol," Domino's Pizza President David Brandon used a 450-degree pizza oven to torch a Subway cease-and-desist letter, which challenged the results of a national taste test.

Other wars revealed the tendency for hostilities to escalate, leading to dirty laundry and mutual damage. As competition increased in the computer business, some attempted to exploit consumers' fears of technology with warnings of how difficult their competitors' products were to use. Others, such as Compaq Computer Corp., implied competitors were on the verge of going bankrupt (Johnson 1993). In the Pizza Wars, Papa John's and Pizza Hut accused (and sued) each other over advertised attacks that one or the other was serving customers either six-day-old dough or stale sauce. This latter episode provided a stunning example of the "dirty laundry effect," as summarized by an observer: "Part of the court hearings involved both chains revealing less than appetizing facts about their sauce preparation processes" (Edwards 2001, 28).

However, few wars more perfectly illustrate hostility escalation and its consequences than Tylenol versus Advil. As one writer concluded, "... the main educational benefit of the Tylenol-Advil war has been to teach the public that you can't believe anything you hear, that the world is unsafe, and that drug companies, behaving like cynical cutthroats, are no better than, well, politicians" (Goldman 1996, 25). After Tylenol user Antonio Benedi successfully sued Johnson \& Johnson for damage to his liver, he published a letter criticizing the company in his hometown newspaper. Advil manufacturer American Home Products then obtained permission to publish the letter in The New York Times (see figure 7). As the same writer noted, "In one voice, the Wall Street analysts and the packaged-goods consultants decried the public confidence-eroding gambit as suicidal for the industry" (Goldman 1996, 26). 


\section{American Express is offering you a new credit card, but you don't have to accept it.}

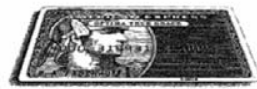

Heck, 7 million merchants donit.

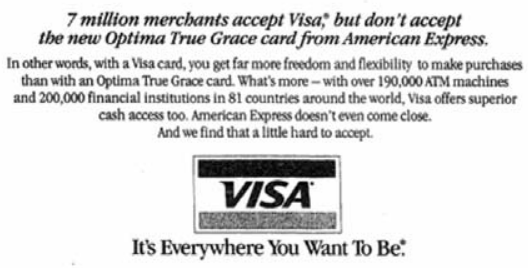

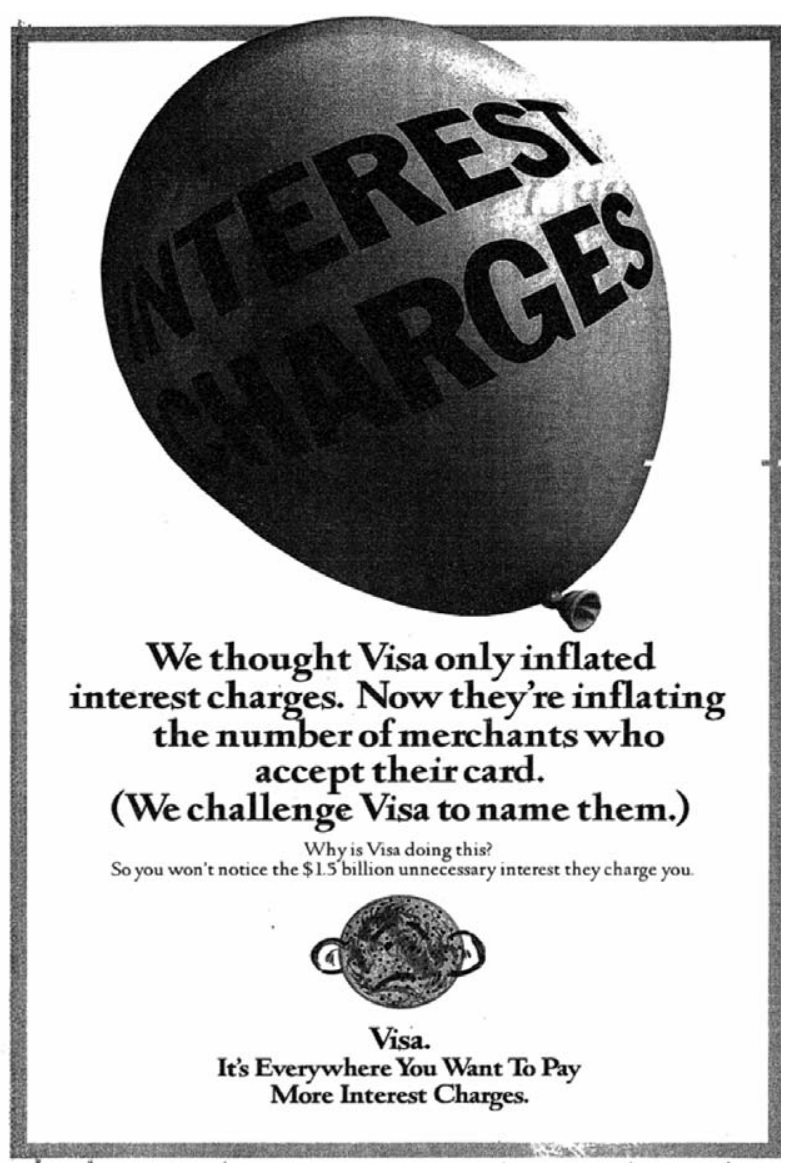

Figure 6. American Express and Visa at War, 1994.

Many sources also mentioned the tendency for combatants to lose focus on selling their products. In the Hardware War, Compaq ran an ad calling for a ceasefire, including the copy "Mudslinging, be it at a political candidate or a computer company, serves little purpose other than to muddy the waters" (Jaben 1992, 3). Referring to the Credit Card Wars, the chairman of a New York management consultancy observed, "It almost becomes defensive communications.... The benefit message is so clouded in irritable language and sort of bullying tactics that I just think most people tune it out" (Levin 1994, 2). Explaining his decision not to join other software vendors in an alliance against Microsoft, a WordPerfect VP-marketing told Business Marketing: "There are times when alliances make a lot of sense, but if the alliance is formed for any other reason than to benefit the customer, it can get off focus" (as cited in Jaben 1992, 3).

Advertising Age summarized many of these problems in an editorial about the Pizza War: "Yet there's a line that should not be crossed. On the wrong side of that line is advertising that loses sight of its selling mission in its eagerness to score points at the rival's expense. Pizza Hut has arrived at that point in its ad war with rival Papa John's" (A food fight out of control 1999, 16). The executive director of a global brand consultancy similarly observed: "I would advise them that they are completely missing the point. ... They're denigrating a brand in the category instead of building their own brand. For any company, I can tell you this advice would be the same" (as cited in Edwards 2001, 30).

The role of the media as arbiters of warfare was also addressed during this period. Fearing it was losing the Cola War, Coca-Cola Co. led a drive to pressure U.S. TV networks to revise their clearance practices. The company called for the change after it took between six weeks and three months for the networks to stop airing a spot in which Pepsi claimed Diet Pepsi was "the taste that beats Diet Coke" (Winters and Walley 1990, 1). Another source observed that the televised portion of the Tylenol-Advil war came to an end when "In the face of all the hubbub and confusion, television networks refused to air the worst of slash-and-burn executions" (Goldman 1996, 26). Network ABC actually banned all comparative drug company spots.

Several sources also mentioned the concern consumers would respond negatively and with confusion. The CEO of agency BBDO/LA observed: "If the negative advertising is scary and manipulative, it's a disaster for a brand" (as cited in Jaben 1992, 3). A Visa USA marketing executive pointed out that "You risk coming off like a bully and no brand really wants that" (as cited in Koprowski 1995, 22). Regarding the 


\section{A RESPONSE to THE MAKERS OF TYLENOL; AND an ImPORTANT Safety Message to CONSUMERS}

Recently you may have seen advertisements in newspapers and on TV across the country from the makers of Tylenol, McNeil-PPC, about use of Tylenol by consumers of alcohol. The ad stated that "when used as directed, it [Tylenol] is the safest type of pain reliever you can buy."

My name is Antonio Benedi. I took Tylenol as directed and lost my liver. I came within hours of death and was saved only by an emergency liver transplant. Later, I won a lawsuit against the McNeil company. The verdict in my favor was recently affirmed by the United States Court of Appeals for the Fourth Circuit, which stated:

"We find that Benedi introduced sufficient evidence from which a reasonable jury could find that McNeil acted with reckless indifference to the health of its consumers."

I am paying for this advertisement from the proceeds of my case against the Tylenol manufacturer to bring to the public's attention some of the facts not included in the recent advertisements from the makers of Tylenol.

I took the recommended dosage of Tylenol to treat the flu-2 tablets 4 times a day over a weekend. Before that, I was accustomed to drinking 2-3 glasses of wine on most nights with dinner. I did not drink alcohol while I was taking the Tylenol. Several days later I was rushed to the hospital in a coma with complete liver failure. A liver transplant saved my life.

The new Tylenol advertisement says "if you're an occasional or moderate consumer of alcohol, you can continue to use Tylenol with confidence." I strongly disagree. The nationally renowned liver experts who testified at my trial also disagree.

We proved in a court of law that the makers of Tylenol had known for more than a decade about the danger of devastating liver injury caused by Tylenol in people who regularly drink alcohol. Liver disease experts had asked the company for many years to warn the public about the risk. Tylenol ignored the plea. We showed at the trial a memorandum dated in 1986 by the makers of Tylenol instructing their sales personnel not to discuss this risk with doctors on their sales routes. This is the same company that advertises Tylenol as "the one doctors recommend most."

All pain relievers have risks. I wanted you, the American public, to know about the specific risk of Tylenol to the liver because it can happen when you are following the directions on the bottle, like I did, and it can turn your life upside down. I think this serious danger to the liver should be mentioned on the Tylenol bottle. Because it isn't, and because the recent Tylenol ads haven't mentioned it, I wanted you to know directly about my experience. 
Credit Card Wars, the president of ad agency Slater Hanft Martin noted, "Our research shows consumers don't want to be a pawn in the fight. They feel the companies are not interested in them and only want to make a sale" (as cited in Koprowski 1995, 22). A veteran of the Hardware Wars also pointed to the concern with backlash: "Last year we responded to negative advertising by IBM by being negative about $\mathrm{OS} / 2$. We got word our customers didn't like it, and we stopped. We were told being negative was not what customers wanted to hear" (as cited in Jaben 1992, 3).

Regarding the war among battery marketers, a senior VP-marketing noted, "I think it's caused consumer confusion.... People hear what are accurate claims [from different types of tests] but contradictory from one competitor to another. ... And because of that, I don't think consumers know what to believe and tend to be more skeptical about the claims" (as cited in Neff 1999, 26). This wasn't the only view, however. As a Visa advertising executive observed, "... veracity tempers an advertising counteroffensive. If people know it's true, that takes away the negative association" (as cited in Koprowski 1995, 22).

\section{Summary and Conclusions}

In general, the findings of this historical study reveal that, at least according to sources published in the marketing and advertising trade literature, advertisers' motives for engaging in advertising warfare, concerns about the potential consequences that might occur, and the consequences that actually did occur, remained quite consistent throughout the past 100 years. Especially noteworthy is the harmonious nature of these beliefs and experiences, as well as the lack of contradictory beliefs.

Specific findings point to the identification of many of the "principles and problems, potential and pitfall" that Startt and Sloan (1989) suggest historical research may facilitate. For instance, it seems apparent that advertising wars may be responsible for many of the negative consequences Pope (1983) attributed to comparative or knocking advertising alone. As the findings of this study show, these consequences - the creation of potentially misleading advertisements, damage to advertising's institutional credibility, and the employment of a mutually damaging form of business rivalry-were among those that often occurred when an advertiser's intended victim chose, instead, to become a foe. These findings are also consistent with those of Beard and Nye (2010), who found that the validity of comparative claims was one of the principal regulatory problems comparative advertising created for the media, as its use expanded in the 1960s and 1970s.

As Grewal et al. $(1997,3)$ note, "The potential for increasing consumers' information was one reason the FTC reputedly did not condemn comparisons ads." Indeed, the FTC began encouraging comparative advertising for exactly this reason. Ironically, the tendency for advertisers to respond to comparative attacks emotionally, for hostilities to escalate, and for advertisers to increasingly lose focus on their own selling points and benefits all suggest that the benefit of much comparative advertising envisioned by the FTC would be unlikely to occur. Similarly, some academic and industry studies suggest consumers often do not respond positively to comparative advertising (for a summary, see Grewal et al. 1997). Sorescu and Gelb $(2000,26)$ also note the "Principal downside to negative advertising is backlash: the perception that negative advertising is unfair or in some other way undesirable." The findings of this study reveal that advertisers were aware of and concerned about this unintended consequence, negative consumer attitudes, throughout the previous century.

The finding that there were often negative outcomes for both combatants and eventually a reluctance to become involved in an advertising war are consistent with recent theory and research on combative advertising. Chen et al. (2009) analyzed the effects of combative advertising and concluded that it could lead to procompetitive outcomes where both firms become collectively worse off because an advertising war often leads to a price war. This study's findings reveal that advertising wars often did occur simultaneously with price wars.

In a conceptual piece on aggressive attack advertising, Beard $(2008,55)$ speculated about what advertisers should do if they are the victims of an attack: "Should they respond?" The findings of this study provide some insights into what the answer to this question might be. Many advertisers expressed regret that they became engaged in advertising wars and, later in the century, began openly acknowledging reluctance to do so. Advertisers should take this into account when considering a response. The findings also point to specific questions that could be asked to assess risk. For instance, is the company, product, or brand especially vulnerable to counterattack? The findings of this study suggest that the answer to this question may almost always be yes. Does the advertiser's industry have dirty laundry? If so, and should hostilities escalate, how likely or severe is the damage that may occur?

Others findings related to responding to an attack point to the possibility that it might be done while avoiding many of the negative consequences of an advertising war. Sources throughout the past 100 years consistently warned that, should advertisers choose to counterattack, they should take special care to stay focused on their own selling points, benefits, and positions. Such a strategy would likely help avoid the escalation of hostilities. More important, and although they were probably not knowingly adopting military strategy, the findings reveal that some advertisers occasionally responded to attacks with what military strategists would call "flanking maneuvers," used to avoid direct, head-on confrontations. Today's advertisers could learn from the experiences of, for instance, Knox gelatin, Coca-Cola, and the Wall Street Journal.

The findings and conclusions of this study are, of course, limited. For example, as noted earlier, although the method is consistent with those of humanistic and empirical historical research, it lacks clear evidence for validity or reliability. Thus, the findings cannot be assumed to be representative of the beliefs of a majority of all advertisers or marketers in any period, but only those of the sources themselves. This study 
is also limited by the sources used for the latter decades of the twentieth century and first decade of the twenty-first century, mainly in that advertisers and executives themselves were generally no longer primary sources. Their beliefs and opinions, although often still in their own words, became filtered by the journalists who interviewed them.

Future research on advertising wars could partly address the limitation of generalizability by identifying a large sample of advertisements representing attacks and counterattacks and content analyzing them. Researchers Karen James and Paul Hensel (1991) argue that a mere comparative ad, in which a competitor is identified for the purposes of claiming superiority, becomes an attack based on (1) the degree to which the targeted competitor is identified, (2) whether the direction of the comparison is differentiative versus associative (i.e., products are presented as different rather than similar), and (3) the extent to which consumers are likely to perceive the advertising to be particularly malicious or unfair. Coding and analyzing attacks and counterattacks using these tactical characteristics would provide valuable insight into an important question suggested by one of this study's major findings: In what specific ways do advertisers lose focus on their own selling points and message strategies?

\section{Declaration of Conflicting Interests}

The author(s) declared no conflicts of interest with respect to the authorship and/or publication of this article.

\section{Funding}

The author(s) received no financial support for the research and/or authorship of this article.

\section{References}

Abrams, B. 1982. Comparative ads are getting more popular, harder hitting. The Wall Street Journal, March 11, 27.

ADA ads aim to tweak conscience of oleo buyers. 1959. Advertising Age, June 15, 8 .

Advertising: A bare-knuckle brawl. 1964. Printers' Ink, October 9, 58. A food fight out of control. 1999. Advertising Age, February 1, 16.

Barry, T. E. 1993. Twenty years of comparative advertising in the United States. International Journal of Advertising 12 (November):325-50.

Barry, T. E., and R. L. Tremblay. 1975. Comparative advertising: Perspectives and issues. Journal of Advertising 4:15-20.

Beard, F. K. 2008. Negative comparative advertising: When marketers attack. In Marketing metaphors and metamorphosis, ed. P. J. Kitchen, 42-56. Houndmills, Basingstoke, Hampshire, UK: Palgrave Macmillan.

Beard, F. K., and C. Nye. 2010. Caught in the middle: A history of the media industry's self-regulation of comparative advertising. Paper presented at the annual conference of the American Academy of Advertising, March, Minneapolis, MN.

Benezra, K. 1998. No holds barred. Adweek, November 9, 46.

Benton, J. 1932. When competitive advertising need not be destructive. Printers' Ink, December 15, 53-5.
Brisacher, E. 1928. Are you riding on the advertising merry-go-round? Printers' Ink, January 5, 161-7.

Broad-gauge advertising. 1906. Printers' Ink, February 12, 30-1.

Brock, L. 1982. How to put down your competition-Tactfully. Direct Marketing, April, 92-3.

Brown, S. W., and D. W. Jackson Jr. 1977. Comparative television advertising: Examining its nature and frequency. Journal of Advertising 6:15-8.

Butler, R. S. 1931. Calls for showdown on competitive copy. Printers' Ink, October 29, 105-6.

Califlorida fight. 1937. Business Week, January 9, 20-1.

Case of the IRA affair. 1985. Banking Advertising News, April 8, 1.

Chen, Yuxin, Y. V. Joshi, J. S. Raju, Z. J. Zhang. 2009. A theory of combative advertising. Marketing Science 28:1-19.

Christopher, M. 1965. National better business bureau hits ads naming competitor as "invidious;" Not so fast, Says ANA. Advertising Age, November 8, 1, 79.

Clifford, S. 2009. Best soup ever? Suits over ads demand proof. The New York Times, November 22, A1.

Comparative ads paying off for Burger King/comparison war incited Wendy's ad campaign. 1984. Marketing News, April 27, 18-9.

Comparisons become invidious in rivalry for tire market. 1931. Business Week, April 22, 9-10.

Competitive or positive; Aesop Glim. 1947. Printers' Ink, December $19,74$.

Copy should avoid criticism of competitors. 1936. Domestic Engineering, October, 83-4.

Dagnoli, J. 1989. Ragu, Prego battle for share heats up. Advertising Age, May 22, 4.

Davidson, K. 1996. What marketers can learn from presidential politics. Marketing News, March 25, 11.

Dichter, E. 1977. Consumers aren't what they used to be-Ads must reflect reaction. Marketing News, October 7, 8 .

Directive 97/55/EC of European Parliament and of the council of 6 October 1997 amending Directive 84/450/EEC concerning misleading advertising so as to include comparative advertising [Online]. Available at http://www.legaltext.ee/text/en/T70690.htm

Ecclesine, J. 1950. Advertising's Hatfields and McCoys. Advertising Agency, September, 66.

Edwards, J. 2001. Sour dough: Pizza Hut v. Papa John's. Brandweek, May 21, 26-8, 30.

Emmrich, S. 1982. How business magazines take shots at each other. Advertising Age, May 3, M6.

Erbes, P.H. 1934. Battle of the fuels. Printers' Ink, September 20, 456.

Fox, S. 1984. The mirror makers: A history of American advertising and its creators. New York: Vintage Books.

Giges, N. 1975. J\&J readies effort to protect Tylenol-new Datril spot sirs. Advertising Age, July 28, 1-61.

1977. Coca Cola-Reluctant entrant into comparative ad warfare. Advertising Age, January 3, 2-75.

1980a. Comparative ads: The headaches of the analgesics. Advertising Age, October 6, 63 64, 66.

1980b. Comparative ads: Battles that wrote the dos and don'ts. Advertising Age, September 29, 59.

Goldman, D. 1996. The pain in our head. Adweek, April 15, 25-6. 
Grewal, D., S. Kavanoor, E. F. Fern, C. Costley, and J. Barnes. 1997. Comparative versus non-comparative advertising: a meta-analysis. Journal of Marketing 61:1-15.

Grey, J. S. 1902. The tobacco war in England. Printers' Ink 40:16.

Hanley, R. T. 1927. An entire industry turns to negative advertising. Printers' Ink, December 29, 10, 12.

Hill, F. T. 1910. Attacks upon competitors shown to be poor policy. Printers' Ink, January 23, 23.

Hisrich, R. D. 1983. Executive advertisers' views of comparison advertising. Sloan Management Review 25 (Fall): 39-50.

Hopkins, C. C. 1930. How far can I go with George Hill. Printers' Ink, April 30, 20.

Hollander, S. C., K. M. Rassuli, D. G. B. Jones, and L. F. Dix. 2005. Periodization in marketing history. Journal of Macromarketing 25:32-41.

How ethics inspired an ad treaty. 1961. Printers' Ink, November 17, 37-9.

How the "big four" cigarette advertisers stand in the 1929 sales battle. 1929. Sales Management, September 28, 563, 592-3.

Hughes, L. M. 1929. Luckies retreat in Sweets War; Expand Advertising Campaign, Sales Management and Advertisers' Weekly 19: 401, 404.

J \& J slashes Tylenol's price, objects to Datril ad approach. 1975. Advertising Age, July 14, 1, 105.

Jaben, J. 1992. Mud wrestling: Microsoft's ads highlight new prominence of negative marketing in business. Business Marketing, August 3, 3.

James, K. E., and P. J. Hensel. 1991. Negative advertising: The malicious strain of comparative advertising. Journal of Advertising 20:53-69.

Johnson, B. 1993. PC giants' ads blast faltering rivals. Advertising Age, January 25, 13.

Just a mosquito bite. 1966. Sales Management, January 7, 78.

Kershaw, A. G. 1976. For and against comparative advertisingAgainst. Advertising Age, July 5, 25-6.

Knox fights back. 1934. Printers' Ink, February 15, 18.

Koprowski, G. 1995. Theories of negativity. Brandweek, February 20, 20-2.

Kramer, L. 1999. Papa John's blasts rival Pizza Hut's ad imagery. Advertising Age, January 25, 4.

Kreisman, R., and C. Marshall. 1982. Burger King's "challenge" set for heavy drive. Advertising Age, September 13, 1, 74.

Laird, P. W. 1998. Advertising progress: American business and the rise of consumer marketing. Baltimore, MD: Johns Hopkins University Press.

Larrabee, C. B. 1934. Too hot to handle. Printers' Ink, February $22,5-59$.

Levin, G. 1994. Marketers get really nasty with in-your-face advertising. Advertising Age, October 17, 2.

Levy, R. 1987. Big resurgence in comparative ads. Dun's Business Month 129:56-8.

Lorillard goads big three in cigarette field. 1928. Sales Management and Advertisers' Weekly, May 26, 856, 862.

Lowry, F. C. 1929. Sugar's reply to Lucky Strikes. Sales Management, December 29, 790, 803.

Lucky Strike and the candy industry mobilize for battle. 1928. Printers' Ink, November 22, 10, 12.
Marchand, R. 1985. Advertising the American dream: Making way for modernity. 1920-1940. Berkeley: University of California Press.

Meyerowitz, S. A. 1985. The developing law of comparative advertising. Business Marketing, August, 81-3, 86.

Meyers, W. 1984. The image-makers: Power and persuasion on Madison Avenue. New York: Times Books.

Moran, B. 1984. BK "battle" settlement "good deal." Advertising Age, August 27, 3, 63.

Muehling, D. D., D. E. Stem Jr., and P. Raven. 1989. Comparative advertising: Views from advertisers, agencies media, and policy makers. Journal of Advertising Research 29:38-48.

Neff, J. 1999. Household brands counterpunch. Advertising Age, November 1, 26.

Overly competitive ads invite action by U.S. 1965. Advertising Age, November 15, 68 .

Pechmann, C., and D. W. Stewart (1990). The development of a contingency model of comparative advertising. Working Paper No. 90-108. Boston: Marketing Science Institute.

Pollay, R. 1985. The subsiding sizzle: A descriptive history of print advertising, 1900-1980. Journal of Marketing, 49:24-37.

Pope, D. 1983. The making of modern advertising. New York: Basic Books.

Presbrey, F. 1929. The history and development of advertising. Garden City, NY: Doubleday.

Prima Donnas at war. 1937. Printers' Ink, July 8, 17.

Rambler taunts trio of rivals in new ad. 1959. Printers' Ink, January $23,11-2$.

Rogers, J. C., and T. G. Williams. 1989. Comparative advertising effectiveness: Practitioners' perceptions versus academic research findings. Journal of Advertising Research (October/November): 22-37.

Round four; Chevrolet lands a blow on Ford in the three-cornered automobile fight. 1933. Printers' Ink, September 7, 11-2.

Rowsome, F., Jr. 1970. They laughed when I sat down: An informal history of advertising in words and pictures. New York: McGraw-Hill.

Santayana, G. 1905. The life of reason [Electronic Version]. Available at http://www.gutenberg.lib.md.us. Accessed on February 9, 2009.

Schudson, M. 1984. Advertising: The uneasy persuasion. New York: Basic Books.

Shimp, T. A. 1975. Comparison advertising in national television commercials: A content analysis with emphasis devoted to the issue of incomplete comparative assertions. In Marketing in turbulent times, ed. E. M. Mazze. Chicago: American Marketing Association.

Smith, M. Y. 1989. The method of history. In Research methods in mass communication (2nd ed.), ed. Guido H. Stempel III and B. H. Westley, 316-30. Englewood Cliffs, NJ: Prentice Hall.

So he bought a horse. 1933. Printers' Ink, September 21, 10.

Sorescu, A. B., and B. D. Gelb. 2000. Negative comparative advertising: Evidence favoring fine-tuning. Journal of Advertising 29:25-40.

Startt, J. D., and W. D. Sloan. 1989. Historical methods in mass communication. Hillsdale, New Jersey: Lawrence Erlbaum.

Stewart, D. W., and D. H. Furse. 1986. Effective TV advertising: A study of 1000 commercials. Lexington, MA: Lexington Books. 
Taschian, R. O., and M. E. Slama. 1984. Involvement and the effectiveness of comparative advertising. In Current issues \& research in advertising, eds. J. H. Leigh, and C. R. Martin Jr. Ann Arbor, MI: The University of Michigan.

Tinsman, R. 1941. Competition jitters. Advertising \& Selling, October 31,64 .

Tires throwing mud. 1931. Printers' Ink, June 10, 20-1.

Underdog advertiser wins in "naming names:" BBDO. 1975. Advertising Age, March 10, 1.

What a bank thinks of the cigarette-sweets war. 1929. Printers' Ink, March 21, 101.

When you knock your competitor you knock advertising! 1931. Advertising \& Selling, November 25, 17-8.

Winters, P., and W. Walley. 1990. Coke seeks tough TV ad watchdog; Herbert criticizes comparative claims. Advertising Age, October 8, 1-2.

Woods, T. 1929. Market opportunities among cigarette manufacturers. The Magazine of Wall Street, August 10, 677-9, 722, 724, 726.

Word war; mayonnaise and salad dressing, steel and steel-wood motor bodies are arguing in public. 1933. Business Week, August 26, 21.
Wright, P. L., and F. Barbour. 1975. The relevance of decision process models in structuring persuasive messages. Communication Research 61:246-59.

York, E. B. 2009. The gloves are off: More marketers opt for attack ads. Advertising Age, May 25, 4, 5.

York, E. B., and N. Zmuda. 2010. So sue me: Why big brands are taking claims to court. AdAge.com (January 4) (accessed January 4, 2010).

\section{Bio}

Fred Beard, $\mathrm{PhD}$, is a tenured professor of advertising in the Gaylord College of Journalism and Mass Communication, University of Oklahoma. His current research interests include comparative advertising, advertising humor, and advertising history. His research has appeared in the Journal of Advertising, the Journal of Advertising Research, the Journal of Business Ethics, the Journal of Business Research, the Journal of Macromarketing, and Journalism History, among several others. 